\title{
Reproducibility of linear measurements performed in dental models from 3D printing
}

\author{
Reprodutibilidade de medições lineares realizadas em modelos odontológicos provenientes de
} impressão 3D

Reproducibilidad de medidas lineales realizadas en modelos dentales a partir de impresión 3D

Fernanda Latorre Melgaço Maia ORCID: https://orcid.org/0000-0001-9699-3972 Faculdade São Leopoldo Mandic, Brazil E-mail: felatorrem@gmail.com Ademir Franco

ORCID: https://orcid.org/0000-0002-1417-2781 Faculdade São Leopoldo Mandic, Brazil E-mail: franco.gat@gmail.com

Daphne Azambuja Hatschbach de Aquino ORCID: https://orcid.org/0000-0002-6390-183X Faculdade São Leopoldo Mandic, Brazil E-mail: daphnemestrado@gmail.com

Luciana Butini Oliveira

ORCID: https://orcid.org/0000-0002-8755-6540 Faculdade São Leopoldo Mandic, Brazil E-mail: luciana.oliveira@ slmandic.edu.br José Luiz Cintra Junqueira ORCID: https://orcid.org/0000-0001-6788-4021 Faculdade São Leopoldo Mandic, Brazil E-mail: joseluiz@slmandic.edu.br Anne Caroline Costa Oenning

ORCID: https://orcid.org/0000-0001-9731-8629 Faculdade São Leopoldo Mandic, Brazil E-mail: anne.oenning@slmandic.edu.br

\begin{abstract}
This study aimed to assess the reproducibility of linear measurements performed in dental models produced via intraoral scanning and three-dimensional (3D) printing using digital light processing (DLP) and fused deposition modeling (FDM). A sample of 22 participants was selected for this study. Intraoral scanning was performed in each participant with TRIOS ${ }^{\mathrm{TM}}$ (3Shape A/S ${ }^{\mathrm{TM}}$, Copenhagen, Denmark) device. The digital models were 3D printed using DLP and FDM techniques. Using a caliper, intraoral linear measurements were performed in situ (on the surface of participant's teeth) and on the 3D printed models. The measurements taken intraoral and on the models were compared using the Intraclass Correlation Coefficient (ICC). The correlation between measurements taken in situ and on DLP models was poor $(<0.4)$, while between in situ and FDM it ranged from poor to satisfactory $(<0.75)$. Generalized linear model showed that the differences did not reach statistically significant levels $(p>0.05)$. According to Bland-Altman approach, the size of measurements did not bias the outcomes. The intraoral scanning and 3D printing techniques used in this study enabled the reproducibility of linear measurements, however, discrete distortions that might be clinically significant occurred.
\end{abstract}

Keywords: Dental models; Intraoral scanning; Imaging; Three-dimensional printing.

\section{Resumo}

O objetivo deste estudo foi avaliar a reprodutibilidade de medidas lineares realizadas em modelos dentais produzidos por escaneamento intraoral e impressão tridimensional (3D) utilizando processamento digital de luz (DLP) e modelagem por deposição fundida (FDM). Uma amostra de 22 participantes foi selecionada para este estudo. A varredura intraoral foi realizada em cada participante com o dispositivo TRIOS TM (3Shape A / S TM, Copenhagen, Dinamarca). Os modelos digitais foram impressos em 3D usando técnicas DLP e FDM. Usando um calibrador, medições lineares intraorais foram realizadas in situ (na superfície dos dentes do participante) e nos modelos impressos em 3D. As medições feitas intraoral e nos modelos foram comparadas usando o coeficiente de correlação intraclasse (ICC). A correlação entre as medições feitas in situ e nos modelos DLP foi fraca $(<0,4)$, enquanto entre in situ e FDM variou de fraca a satisfatória $(<0,75)$. O modelo linear generalizado mostrou que as diferenças não 
atingiram níveis estatisticamente significantes ( $p>0,05)$. De acordo com a abordagem de Bland-Altman, o tamanho das medidas não influenciou os resultados. As técnicas de digitalização intraoral e impressão 3D utilizadas neste estudo possibilitaram a reprodutibilidade das medidas lineares, porém, ocorreram discretas distorções que podem ser clinicamente significativas.

Palavras-chave: Modelos odontológicos; Escaneamento intraoral; Imaginologia; Impressão 3D.

\section{Resumen}

El objetivo fue evaluar la reproducibilidad de las mediciones lineales realizadas en modelos dentales producidos mediante escaneo intraoral e impresión tridimensional (3D) utilizando procesamiento de luz digital (DLP) y modelado de deposición fundida (FDM). Se seleccionó una muestra de 22 participantes para este estudio. Se realizó una exploración intraoral en cada participante con el dispositivo TRIOS TM (3Shape A / S TM, Copenhague, Dinamarca). Los modelos digitales se imprimieron en 3D utilizando técnicas DLP y FDM. Con un calibre, se realizaron mediciones lineales intraorales in situ (en la superficie de los dientes de los participantes) y en los modelos impresos en 3D. Las medidas tomadas intraoralmente y en los modelos se compararon utilizando el coeficiente de correlación intraclase (ICC). La correlación entre las medidas tomadas in situ y en los modelos DLP fue pobre $(<0,4)$, mientras que entre in situ y FDM varió de mala a satisfactoria $(<0,75)$. El modelo lineal generalizado mostró que las diferencias no alcanzaron niveles estadísticamente significativos ( $>>0.05$ ). Según el enfoque de Bland-Altman, el tamaño de las mediciones no sesgó los resultados. Las técnicas de escaneo intraoral e impresión 3D utilizadas en este estudio permitieron la reproducibilidad de las mediciones lineales, sin embargo, se produjeron distorsiones discretas que podrían ser clínicamente significativas.

Palabras clave: Modelos dentales; Exploración intraoral; Imágenes; Impresión tridimensional.

\section{Introduction}

Dental casts are well-known components of the armamentarium of Dentistry. In practice, this clinical tool is designed to support treatment planning and follow-up (Wutzl et al. 2009; Pacheco et al. 2019; Di Ventura et al. 2019; Franco et al. 2019). However, the most significant contribution of this technology relies in the orthodontic practice - in which precision becomes the core goal to be achieved for fabricating orthodontic appliances. Over the last decades, dental casts were built-up in plaster from dental impressions through a conventional technique consolidated over the last decades. Recently, the inherent distortion that eventually occurs from the manual manipulation of dental impression and casts gained space in the spotlight of interest in dental science (Garino \& Garino 2002; Sanches et al. 2013; Vitti et al. 2013). Intraoral scanning emerged as a hightech alternative to register the occlusion and dental arrangement in a virtual environment (Abduo \& Elseyoufi 2018). The analysis and navigation on dental surfaces enabled a computer-guided interaction with the patient and a dynamic prediction and simulation of orthodontic movement (Nabbout \& Baron 2017; Mangano et al. 2017).

In addition to this new scenario, three-dimensional (3D) printing followed the technological evolution and became available for dentists interested in having the solid reproduction of the intraoral scanned material, as well as for companies interested in designing digitally planned appliances. The benefits of this technology expanded more evidently towards Orthodontics, Orthopedics and Maxillofacial Surgery (Lee et al. 2015; Mok et al. 2016; Tao et al. 2019). However, in order to achieve optimal performances, devices and techniques must be tested and filtered based on their effectiveness. Currently, there are different types of 3D printers (Dawood et al. 2015; Brown et al. 2018), among those there are printers based on Digital Light Processing (DLP) and fused deposition modeling (FDM). In short, DLP works in a light-guided and controlled environment to design objects or even separate layers in photocurable resin (Mu et al. 2017; Zhang et al. 2019). FDM technique works as a robotic gluing machine for polylactic acid or acrylonitrile butadiene styrene (Dawood et al. 2015). Software-guided commands are given so the digital model is sliced in parts and built together in a thermoplastic reaction (Dawood et al. 2015).

The scientific problem explored in this study relies on the fact that the technological workflow to reach a final 3D printed model may be susceptible to mistakes from intraoral scanning to the $3 \mathrm{D}$ printing process. Based on the hypothesis that distortions may occur in printed models and justified on the need for supporting the dental practice with reliable tools, the aim 
of this study was to assess the reproducibility of linear measurements performed in dental models from intraoral scanning and 3D printing with DLP and FDM techniques.

\section{Materials and Methods}

\subsection{Ethical aspects and study design}

This observational study was carried out with ethical clearance from the Local Human Ethics Committee, protocol \#3.204.760.

\subsection{Participants and sampling}

Twenty-two participants were selected for this study and the sample size was established based on previous investigations (Pandis 2012). According to the eligibility criteria male and female participants aged above 16 years were included. All the eligible patients were under dental treatment and needed dental impression. Participants with missing canines and molars were excluded, as well as participants with fixed orthodontic appliances and dental anomalies.

\subsection{Data collection and variables}

From each participant, intraoral measurements were taken with a digital caliper (Starrett, Athol, MA, USA). The measurements consisted of the intercanine distance - taken between the incisal edges of contralateral canines, and the intermolar distance - taken between the edges of the mesiobuccal cusps of contralateral first molars. The measurements were performed in the maxillary and mandibular arches. This quality-control procedure assured a gold-standard parameter for comparison with measurements taken in future steps. Next, all the participants underwent intraoral scanning with TRIOS (3Shape A/S ${ }^{\mathrm{TM}}$, Copenhagen, Denmark) device. The scanning procedure followed instructions of the manufacturer and was accomplished between 5 and 10 minutes for each participant. The obtained scanning records were exported in .stl format for 3D printing. The printing process was performed in DLP and FDM technology using Duplicator $7^{\mathrm{TM}}$ (Wanhao ${ }^{\mathrm{TM}}$, Dallas, TX, USA) and Da Vinci $1.0 \mathrm{AiO}^{\mathrm{TM}}$ (XYZPrinting Inc. ${ }^{\mathrm{TM}}$, Taiwan) devices. Intercanine and intermolar measurements were performed on the DLP and FDM 3D printed models. The 3D printing included models scanned at 100 $\mu \mathrm{m}$. The DLP printing used a wavelength between 380 to $405 \mathrm{~nm}$ to build-up models from photocurable resin (DM450, MakerTech Labs ${ }^{\mathrm{TM}}$, Tatuí, Brazil). The initial layers were printed in 60 seconds each, while the remaining layers in 5 seconds each. The FDM printing worked with Acrylonitrile Butadiene Styrene filament considering layer thickness of $0.2 \mathrm{~mm}$.

\subsection{Error of the method}

Intra-examiner reproducibility was tested by repeating twice each of the measurements on each model within an interval of 30 days. Two examiners were included in the study and performed twice each of the measurements on DLP and FDM models within the same time interval to enable inter-examiner reproducibility testing. For statistical purposes, the mean value of the three measurements performed by the main examiner was considered.

\subsection{Data analysis}

Data was initially assessed for normality of distribution. The variables (four measurements performed intraoral, on DLP and on FDM) were treated with descriptive statistics. The comparison between measurements was performed within a generalized linear model. Intraclass Correlation Coefficient (ICC) and Bland-Altman statistics were used in order to assess the reproducibility of the intraoral measurements with the measurements performed on 3D printed models. ICC was interpreted as poor $(<0.4)$, satisfactory $(0.4-0.75)$, and excellent $(>0.75)$ (Szklo \& Nieto 2019). Statistic tests were performed in R Core Team 
(R Foundation, Vienna, Austria) software package. Statistical significance was set at 5\% and the confidence interval at $95 \%$.

\section{Results}

Descriptive statistics showed that the mean maxillary intercanine measurements reached $35.68( \pm 3.09), 36.05( \pm 2.05)$, and $34.95( \pm 3.24) \mathrm{mm}$ in intraoral, DLP and FDM analyses, respectively, while for the same analyses the mean maxillary intermolar measurements reached $53.34( \pm 3.71), 53.64( \pm 4.06)$, and $52.61( \pm 3.97) \mathrm{mm}$. In the mandible, the mean intercanine measurements reached $26.48( \pm 3.22), 26.86( \pm 2.38)$, and $27.07( \pm 2.62) \mathrm{mm}$, while the intermolar measurements reached 46.11 $( \pm 4.84), 47.45( \pm 4.65)$, and $47.36( \pm 4.79) \mathrm{mm}$ for intraoral, DLP and FDM analyses, respectively (Table 1$)$. Figure 1 presents boxplots for a clear spatial visualization of the measurements taken intraoral and on DLP and FDM. According to the generalized linear model, statistically significant differences between measurements taken in each of the analyses were not detected $(\mathrm{p}>0.05)$. 
Research, Society and Development, v. 10, n. 11, e344101113370, 2021

(CC BY 4.0) | ISSN 2525-3409 | DOI: http://dx.doi.org/10.33448/rsd-v10i11.13370

Table 1 - Descriptive statistics of the measurements performed in intraoral, on SLA and on FDM models.

\begin{tabular}{|c|c|c|c|c|c|c|c|}
\hline \multirow{2}{*}{ Arch } & \multirow{2}{*}{ Measurement } & \multicolumn{2}{|c|}{ Intraoral } & \multicolumn{2}{|c|}{ SLA models } & \multicolumn{2}{|c|}{ FDM models } \\
\hline & & Mean (SD) & Median (mín; max) & Mean (SD) & Median (mín; max) & Mean (SD) & Median (mín; max) \\
\hline \multirow{2}{*}{ Maxillary } & Intercanine & $35.68(3.09)$ & $36.00(30.00 ; 40.50)$ & $36.05(2.65)$ & $36.00(30.00 ; 41.50)$ & $34.95(3.24)$ & $35.25(26.50 ; 40.00)$ \\
\hline & Intermolar & $53.34(3.71)$ & $54.00(42.00 ; 60.00)$ & $53.64(4.06)$ & $54.00(40.00 ; 60.50)$ & $52.61(3.97)$ & $54.00(40.00 ; 58.00)$ \\
\hline \multirow{2}{*}{ Mandibular } & Intercanine & $26.48(3.22)$ & $26.75(20.00 ; 32.50)$ & $26.86(2.38)$ & $26.50(22.00 ; 32.50)$ & $27.07(2.62)$ & $27.00(22.00 ; 31.50)$ \\
\hline & Intermolar & $46.11(4.84)$ & $47.25(32.00 ; 52.50)$ & $47.45(4.65)$ & $49.00(30.50 ; 52.50)$ & $47.36(4.79)$ & $47.75(33.00 ; 58.00)$ \\
\hline
\end{tabular}

SD: standard deviation; SLA: stereolithography apparatus; FDM: fusion and deposition modeling. Source: Authors.

Figure 1 - Boxplots for the spatial visualization and comparison between maxillary (A and B) and mandibular (C and D) measurements taken intraoral (navy blue), on SLA (light blue) and on FDM (grey) 3D printed models.
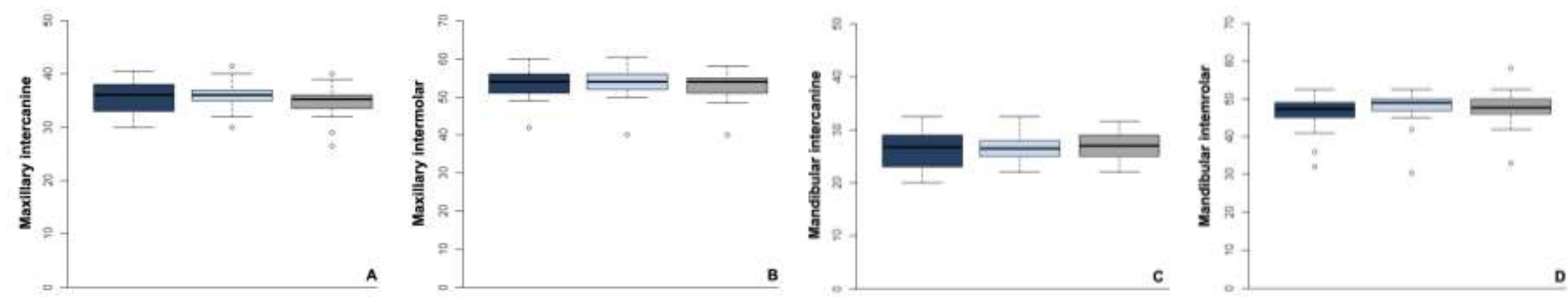

- Intraoral $\square$ SLA $\square$ FDM

Source: Authors. 
ICC outcomes showed that the intraoral measurements had a poor $(<0.4)$ reproducibility when taken on DLP and FDM 3D printed models, except for the mandibular intercanine distance that was slightly satisfactory (ICC: 0.46). BlandAltman quantified the bias within measurements and showed values of 0.36 and -0.73 , for the reproducibility of intraoral maxillary intercanine measurements on DLP and on FDM, respectively; and 0.3 and -0.73 for the intraoral maxillary intermolar measurements. In the mandible, the reproducibility of intraoral intercanine measurements on DLP and on FDM models reached 0.39 and 0.59 , respectively, while the intermolar measurements reached 1.34 and1.25, respectively (Table 2). Graphic visualization of these findings separately for the reproduction of intraoral measurements on DLP and FDM models is found in the scatter plots of Figures 2 and 3, respectively.

Table 2 - Reproducibility of intraoral measurements on SLA and FDM 3D printed models.

\begin{tabular}{c|c|cccc}
\hline \multirow{2}{*}{ Arch } & \multirow{2}{*}{ Measurement } & \multicolumn{2}{|c}{ Intraoral x SLA } & \multicolumn{2}{c}{ Intraoral x FDM } \\
\cline { 3 - 6 } & & Bland-Altman & ICC & Bland-Altman & ICC \\
\hline \multirow{2}{*}{ Maxillary } & Intercanine & $0.36(-6.09 ; 6.82)$ & $0.31(-0.10 ; 0.66)$ & $-0.73(-8.21 ; 6.76)$ & $0.24(-0.20 ; 0.60)$ \\
& Intermolar & $0.30(-8.64 ; 9.23)$ & $0.30(-0.14 ; 0.64)$ & $-0.73(-9.18 ; 7.72)$ & $0.34(-0.09 ; 0.67)$ \\
\hline \multirow{2}{*}{ Mandibular } & Intercanine & $0.39(-5.91 ; 6.69)$ & $0.35(-0.08 ; 0.67)$ & $0.59(-5.36 ; 6.55)$ & $0.46(0.04 ; 0.74)$ \\
& Intermolar & $1.34(-9.46 ; 12.15)$ & $0.26(-0.18 ; 0.62)$ & $1.25(-9.00 ; 11.50)$ & $0.37(-0.06 ; 0.68)$ \\
\hline
\end{tabular}

SLA: stereolithography apparatus; FDM: fusion and deposition modeling; ICC: intraclass correlation coefficient. Source: Authors.

Figure 2 - Scatter plots for the visualization of reproducibility of intraoral maxillary and mandibular measurements on SLA 3D printed models showing outcomes of bias, upper limit of agreement (LSC) and lower limit of agreement (LIC).

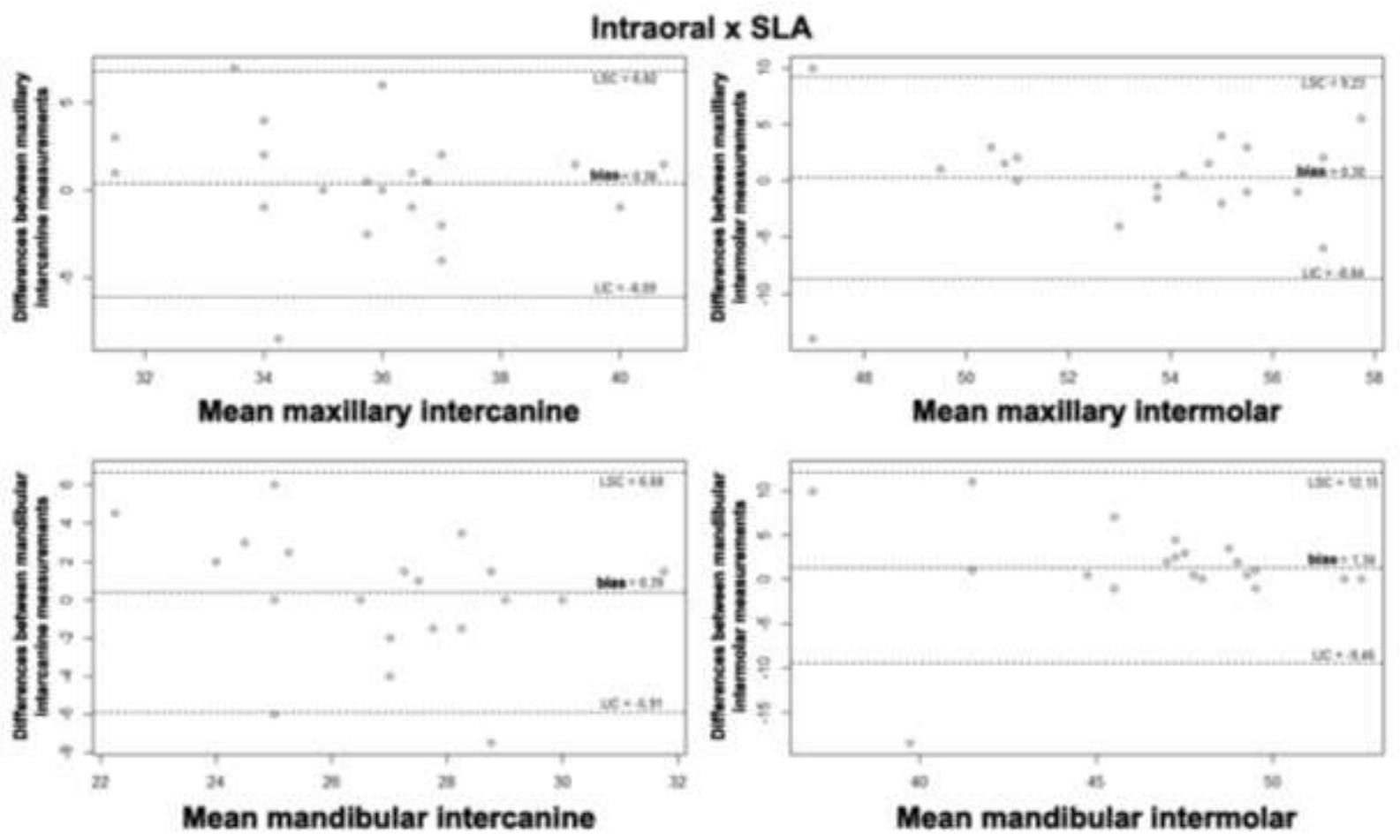

Source: Authors.

\section{Discussion}

The advances in technology depicted from the contemporary health sciences contributed to more straight forward procedures in the clinical practice (Van Noort 2012). Intraoral scanning and 3D printing emerged as fast, clean and eventually 
precise alternatives to replace conventional dental impression and dental model plaster casting, respectively. Evidently fast and clean, both technologies stills lack scientific evidence to prove their absolute accuracy for fabrication of specific components of the treatment, such as orthodontic appliances. This study combined innovative technology to test the reliability of intraoral scanning and 3D printing based on metric reproduction of interdental distances.

Figure 3 - Scatter plots for the visualization of reproducibility of intraoral maxillary and mandibular measurements on FDM 3D printed models showing outcomes of bias, upper limit of agreement (LSC) and lower limit of agreement (LIC).
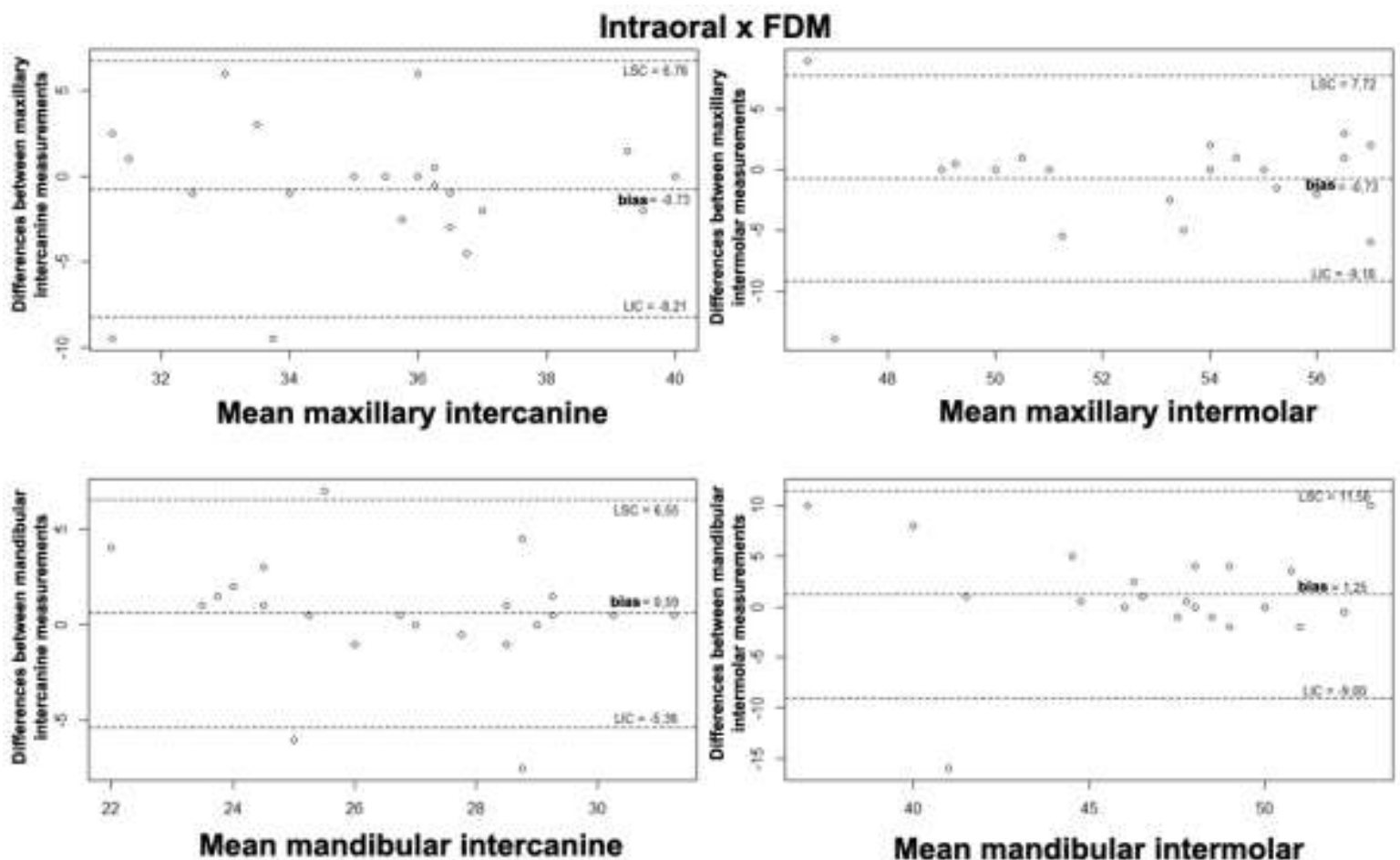

Source: Authors.

In order to enable a reliable comparative basis in this study, the methodological set up was designed establishing intraoral measurements as reference-standard to be compared with the other analysis. The decision for intraoral measurements differs from most of the studies available in the scientific literature - which establish as reference measurements performed on dental plaster casts (Kasparova et al. 2013; Rebong et al. 2018; Zhang et al. 2018). The rationale behind choosing intraoral measurements instead of measurements on dental plaster casts relied on the inherent distortion that is usually found in the latter. Moreover, studies that compare models from intraoral scanning and conventional dental impression increase the discomfort to the sampled participants that undergo two replaceable procedures. On the other hand, by solely choosing intraoral measurements distortions and discomfort is reduced, while realistic metric information of the distances of interest are obtained.

The first outcomes of this study are presented as descriptive information in Table 1. In short, the mean values of the intraoral measurements and measurements on DLP and FDM 3D printed dental models are reported. Similarity between measurements is observed between the three different analyses and is confirmed with the generalized linear regression model, which pointed towards lack of statistically significant differences ( $p>0.05$ ). Authors that compared dental measurements taken form plaster casts and 3D printed models also reported lack of significant differences between both (Kasparova et al. 2013; Rebong et al. 2018; Zhang et al. 2018). In other studies, specific measurements were found to be different between original and 
3D printed models, such as crown height (Brown et al. 2018). In the present study, specific measurements also showed more variation than others, namely the mandibular intermolar distance. This measurement presented the highest bias according to Bland-Altman testing. The scientific literature corroborates this finding by showing other examples of outcomes that resulted in higher error rates for measurements in the mandible compared to the maxilla (Rossini et al. 2016). A possible explanation for this phenomenon is the presence of saliva and position and movement of the tongue that may have a negative impact during intraoral data acquisition (Arakida et al. 2018). Other justification is the attrition that may be found in canine and molar crowns that flattens the cusps and hampers the identification of a reference point for taking measurements.

Data reported in Table 2 demonstrates how similar DLP and FDM 3D printing techniques performed compared to the intraoral measurements. Only discrete differences within the measurements were detected. Confirming recent outcomes from the scientific literature (Zhang et al. 2018), these findings converge for the use of 3D printed models in practice. On the other hand, it must be noted that despite the lack of statistically significant differences between measurements taken intraoral/DLP and intraoral/FDM, the differences might be clinically relevant. The scientific literature points out to acceptance thresholds that could enable inferences based on the reproducibility and reliability of the method (Dietrich et al. 2017). Authors have suggested that the differences between measurements (error) performed in conventional and scanned dental casts should not extrapolate the range from $2 \mathrm{~mm}$ (Schirmer \& Wiltshire 1997) to 3mm (Hirogaki et al. 2001). In the present study, the difference between the means of linear measurements comparing intraoral measurements with measurements in DLP digital models ranged between 0.3 and $1.34 \mathrm{~mm}$, while between intraoral measurements and FDM digital models ranged between 0.59 and $1.25 \mathrm{~mm}$. These outcomes reveal that linear measurements in DLP and FDM digital models may not be as accurate as necessary.

Examiner reproducibility outcomes must be taken into account as a topic to be addressed and considered in future studies, especially because they were suboptimal. Testing the performance of examiners with different experience of practice could be included in this context. Increasing the number of dependent variables (measurements) could be considered in order to test the performance of the intraoral scanning and 3D printing devices in other anatomic regions of the models and in different directions (not only horizontal as intercanine and intermolar, but also vertical and oblique). Finally, other intraoral scanners and 3D printers could be tested and compared.

\section{Conclusion}

There was no statistically significant difference between intraoral measurements and measurements taken in 3D printed models via DLP and FDM. The intraoral scanning and 3D printing techniques used in this study enabled the reproducibility of linear measurements, however, discrete distortions that might be clinically significant occurred.

\section{Disclosure}

The authors do not have any financial interests or commercial associations to disclose. All authors have viewed and agreed to the submission of this article.

\section{References}

Abduo, J., \& Elseyoufi, M. (2018). Accuracy of intraoral scanners: a systematic review of influencing factors. Eur J Prosthodont Restor Dent, 30:101-121. http://doi.org/10.1922/EJPRD_01752Abduo21.

Arakida, T., Kanazaw, A. M., Iwaki, M., Suzuki, T., \& Minakuchi, S. (2018). Evaluating the influence of ambient light on scanning trueness, precision, and time of intra oral scanner. J Prothodontic Res, 62:324-329. https://doi.org/10.1016/j.jpor.2017.12.005.

Brown, G. B., Currier, G. F., Kadioglu, O., \& Kierl, J. P. (2018). Accuracy of 3-dimensional printed dental models reconstructed from digital intraoral impressions. Am J Orthod Dentofac Orthop, 154:733-739. https://doi.org/10.1016/j.ajodo.2018.06.009 
Dawood, A., Marti, B. M., Sauret-Jackson, V., \& Darwood, A. (2015). 3D printing in dentistry. Br Dent J, 219:521-529. http://doi.org/10.1038/sj.bdj.2015.914

Di Ventura, A., Lanteri, V., Farronato, G., Gaffuri, F., Beretta, M., Lanteri, C., \& Cossellu, G. (2019). Three-dimensional evaluation of rapid maxillary expansion anchored to primary molars: direct effects on maxillary arch and spontaneous mandibular response. Eur J Pediatr Dent, 20:38-42. http://doi.org/ 10.23804/ejpd.2019.20.01.08.

Dietrich, C. A., Ender, A., Baumgartner, S., \& Mehl, A. (2017). A validation study of reconstructed rapid prototyping models produced by two technologies. Angle Orthod, 87:782-787. https://doi.org/10.2319/01091-727.1.

Franco, R. P. A. V., Mobile, R. Z., Filla, C. F. S., Sbalqueiro, R., de Lima, A. A. S., Silva, R. F., Paranhos, L. R., Tanaka, O. M., Turkina, A., \& Franco, A. (2019). Morphology of the palate, palatal rugae pattern, and dental arch form in patients with schizophrenia. Special Care Dent, 39(5):464-470. http://doi.org/ $10.1111 / \mathrm{scd} .12408$

Garino, F., \& Garino, G. B. (2002). Comparison of dental arch measurements between stone and digital casts. World J Orthod, 3:250-254. http://doi.org/10.1.1.610.5420

Hirogaki, Y., Sohmura, T., Satoh, H., Takahashi, J., \& Takada, K. (2001). Complete 3-D reconstruction of dental cast shape using perceptual grouping. IEEE Trans Med Imag, 20:1093-1101. http://doi.org/10.1109/42.959306.

Kasparova, M., Grafova, L., Dvorak, P., Dostalova, T., Prochazka, A., Eliasova, H., Prusa, J., \& Kakawand, S. (2013). Possibility of reconstruction of dental plaster cast from 3D digital study models. Biomed Eng (Online), 12:49. http://doi.org/10.1186/1475-925X-12-49.

Lee, K. Y., Cho, J. W., Chang, N. Y., Chae, J. M., Kang, K. H., Kim, S. C., \& Cho, J. H. (2015). Accuracy of three-dimensional printing for manufacturing replica teeth. Korean J Orthod, 45:217-225. http://doi.org/10.4041/kjod.2015.45.5.217.

Mangano, F., Gandolfi, A., Luongo, G., \& Logozzo, S. (2017). Intraoral scanners in dentistry: a review of the current literature. BMC Oral Health, 17:149. http://doi.org/10.1186/s12903-017-0442-x.

Mok, S. W., Nizak, R., Fu, S. C., Ho, K. W. K., Qin, L., Saris, D. B. F., Chan, K. M., \& Malda, J. (2016). From the printer: Potential of three-dimensional printing for orthopaedic applications. J Orthop Translat, 6:42-49. http://doi.org/10.1016/j.jot.2016.04.003.

Mu, Q., Wang, L., Dunn, C. K., Kuang, X., Duan, F., Zhang, Z., Qi, H. J., \& Wang, T. (2017). Digital light processing 3D printing of conductive complex structures. Add Manufac, 18; 74-83. https://doi.org/10.1016/j.addma.2017.08.011

Nabbout, F., \& Baron, P. (2017). Orthodontics and dental anatomy: three-dimensional scanner contribution. J Int Soc Prev Community Dent, 7:321-328. http://doi.org/10.4103/jispcd.JISPCD_394_17.

Pacheco, A. A. R., Franco, A., Antelo, O. M., Pithon, M. M., \& Tanaka, O. M. (2018). Changes in the mandibular arch after rapid maxillary expansion in children: A three-dimensional analysis using digital models. Eur J Gen Dent, 7:47-50. http://doi.org/10.4103/ejgd.ejgd_95_18

Pandis, N. (2012). Sample calculations for comparison of 2 means. Am J Orthod Dentofac Orthop, 141:519-521. http://doi.or/10.1016/j.ajodo.2011.12.010.

Rebong, R. E., Stewart, K. T., Utreja, A., Ghoneima, A. A. (2018). Accuracy of three-dimensional dental resin models created by fused deposition modeling, stereolithography, and Polyjet prototype technologies: a comparative study. Angle Orthod, 88:363-369. http://doi.org/10.2319/071117-460.1

Rossini, G., Parrini, S., Castroflorio, T., Deregibus, A., \& Debernardi, C. L. (2016). Diagnostic accuracy and measurement sensitivity of digital models for orthodontic purposes: A systematic review. Am J Orthod Dentofac Orthop, 149:161-170. http://dx.doi.org/10.1016/j.ajodo.2015.06.029.

Sanches, J. O., Santos-Pinto, L. A. M., Santos-Pinto, A., Grehs, B., \& Jeremis, F. (2013). Comparison of space analysis performed on plaster vs. digital dental casts applying Tanaka and Johnston's equation. Dental Pres J Orthod, 18:128-133. http://doi.org/10.1590/S2176-94512013000100024.

Schirmer, U. R., \& Wiltshire, W. A. (1997). Manual and computer-aided space analysis: a comparative study. Am J Orthod Dentofacial Orthop, 112:676-680.

Szklo, M., \& Nieto, F. J. (2018). Epidemiology: beyond the basics. (4th ed.), Jones \& Bartlett Learning, USA.

Tao, O., Kort-Mascort, J., Lin, Y., Pham, H. M., Charbonneau, A. M., ElKashty, O. A., Kinsella, J. M., \& Tran, S. D. (2019). The applications of 3d printing for craniofacial tissue engineering. Micromachines (Basel), 10:480. http://doi.org/10.3390/mi10070480.

Van Noort, R. (2012). The future of dental devices is digital. Dental Mat, 28:3-12.

Vitti, R. P., Da Silva, M. A. B., Consani, R. L. X., \& Sinhoreti, M. A. C. (2013). Dimensional accuracy of stone casts made from silicone-based impression materials and three impression techniques. Braz Dent J, 24:498-502. http://doi.org/10.1590/0103-6440201302334.

Wutzl, A., Sinko, K., Shengelia, N., Brozek, W., Watzinger, F., Schicho, K., \& Ewers, R. (2009). Examination of dental casts in newborns with bilateral complete cleft lip and palate. Int J Oral Maxillofac Surg, 38:1025-1029. http://doi.org/ 10.1016/j.ijom.2009.04.023

Zhang, H., Yin, L., Liu, Y., Yan, L., Wang, N., Liu, G., An, X., \& Liu, B. (2018). Fabrication and accuracy research on 3D printing dental model based on cone beam computed tomography digital modeling. West China J Stomatol, 36:156-161. http://doi.org/10.7518/hxkq.2018.02.008.

Zhang, Z. C., Li, P. L., Chu, F. T., \& Shen, G. (2019). Influence of the three-dimensional printing technique and printing layer thickness on model accuracy. $J$ Orofac Orthop, 80; 194-204. http://doi.org/ 10.1007/s00056-019-00180-y 